\title{
Migrant Farm Workers Exposed to Pesticides in Sinaloa, Mexico
}

\author{
Anthon Alvarez A. and Alba D. Campaña S. \\ Faculty of Medicine University of Sinaloa \\ Mexico
}

\section{Introduction}

Mexico is one of the major importers of pesticides in the whole of Latin America. Farm workers represent one of the poorest sectors of the population in Mexico. Every harvest season, an estimated 300,000 children between the ages of 6 and 14 migrate to the northwest part of this country along with their parents, who have been contracted to work in the fields. At about age 10, half of those children begin working, and the number rises sharply as they get older. The inclusion of workers in the agricultural labor process depends on the following stages: seed, staking, weeding, cutting, harvesting and packing in addition to the application of pesticides, (the organophosphates and carbamates types are used more frequently) (Palacios et al., 2000).

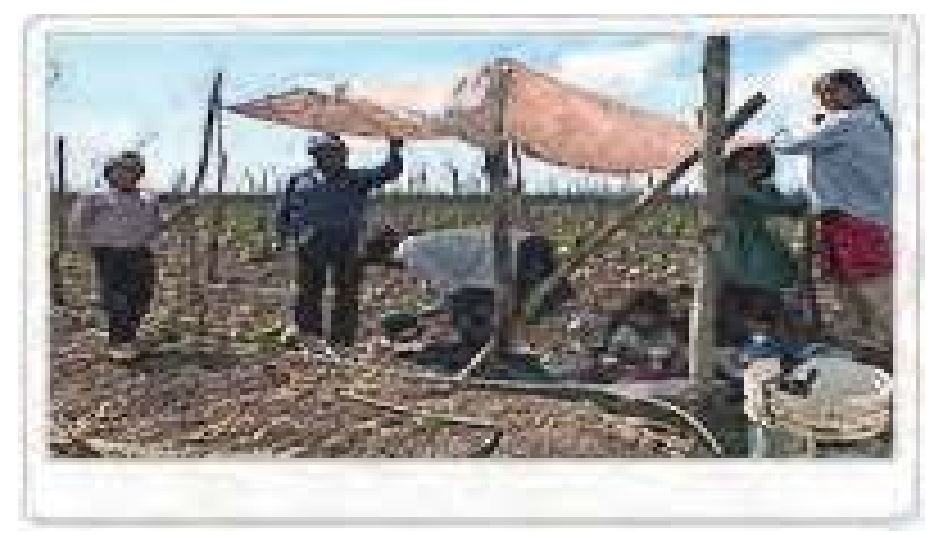

Fig. 1. SINALOA STATE, Mexico By Thomas Nybo

Sinaloa State, Mexico is a federal entity in which there is extensive agricultural development and where production is mainly for the export market and less for the domestic one. Highly technical production processes are used which reduce cropping areas, but whose performance has increased the demand day laborers. According to (Secretaría de Agricultura, Ganadería, Desarrollo Rural, Pesca y Alimentación [SAGARPA], 2004), the agricultural area amounts to 1 '266, 120 hectares (one hectare $=2.471$ acres) and 1,175,425 hectares are harvested. 
These are large producers, who spend their production to foreign markets mainly medium and small and primarily oriented to the internal market.

According to the situational diagnoses made by the Laborers Care Program, agricultural day laborers amounted to 113 thousand people, of whom 72000 are mostly migrants from the states of Guerrero and Oaxaca. The type of migration that occurs is primarily family and to a lesser extent, men migrating alone. Some $33.08 \%$ of the population is reported to be illiterate, of which $42.32 \%$ are male and $57.68 \%$ are women, while $45.07 \%$ are children between 6 and 14 who cannot read or write. Northern, it includes the towns of Ahome, El Fuerte, Choix, Guasave, and Angostura, where vegetables, grains and fodder are the main produce. In 2003 there was an estimated (Programa Nacional de Jornaleros Agrícolas. [PRONJAG], 2006), laborer population of 38.092 workers, of whom 31.371 were considered migrant population. A feature of this area is that the largest number of migrants are from the same state. Center Zone, corresponds to the Valley of Culiacan and municipalities, Elota, Mocorito and Navolato, producing mainly vegetables (tomato, tomato, cucumber, zucchini, eggplant), which are channeled to the export market, also corn and fodder that are destined for the domestic market. There are about 67 thousand laborers.

According to some studies (Palacios-Nava et al., 2004) on socio-demographic characteristics, the migrant population usually consists of about $75 \%$ to $25 \%$ men to women. The majority of the migrant population is young. However, this feature is accentuated in the case of women, since significant differences were found in the age distributions according to sex ( $\mathrm{p}$ $=0.000$ ). Of all women, $23 \%$ were between 8 and 14 years of age, while only $8.2 \%$ of men were found in that age. It was noted that female participation decreased as age increased, so that $76 \%$ of women were between 8 and 34 , and $82 \%$ of men between 15 and 44 . One of the most important migrations is to move day laborers pole to pole group of agricultural development, $91 \%$ women traveled with their families, whereas the figure for men was $65 \%$ $(p=0.000)$. There were no differences in marital status; a large percentage (58) were married, $37.7 \%$ single and the percentage of widowed or divorced was slightly higher in women than the figures for men (4.1 vs. 1.3\%). According to a survey of 8117 heads of household laborers in the main farming region, $29.3 \%$ were born in the State of Guerrero (Grammont \& Lara, 2004). The migrant's social networks play a fundamental role in availability of casual labor. Flexible production, efficiency and low cost, despite its limitations, is played over time, and according to the (Secretaria de Desarrollo Social [SEDESOL], 2004), they exceed 10000 per season.

Significant differences were observed in place of origin $(p=0.000)$, the majority of women were from the states of Guerrero (47\%), Oaxaca (25\%) and Veracruz $(16 \%)$, while men came mostly from Guerrero 37\%), Sinaloa (24\%) and Veracruz (22\%). Most women traveling alone were from the state of Oaxaca.

The majority are migrants, mostly from the states of Guerrero, Oaxaca and other entities in the country. This migration has a family character. South Zone, includes the towns of Mazatlan, Rosario, and Escuinapa producing mainly chilli and mangoes. The labor force used is mostly local in character, amounting to 33 thousand people (Ramirez-Romero et al., 2006) (Table 1).

Only 1 in 10 of the child workers attends school, and even fewer finish a primary education. Migrant farm workers typically arrive in Sinaloa in September or October and work until early May. Most of the children working in the fields are not only deprived of an education but also face considerable dangers in the exposure to pesticides. (The United Nations 


\begin{tabular}{|c|c|c|c|c|}
\hline \multicolumn{5}{|c|}{ Migrant laborer population in the Labor Market } \\
\hline State & labor market & total & locales & migrants \\
\hline \multirow[t]{6}{*}{ Baja California } & Mexicali & 12,000 & 9,600 & 2,400 \\
\hline & San Quintin & 25,000 & 10,000 & 15,000 \\
\hline & Maneadero & 1,500 & 450 & 1,050 \\
\hline & Ojos negros & 1,800 & 180 & 1,620 \\
\hline & Guadalupe & 300 & 60 & 240 \\
\hline & $\begin{array}{c}\text { Eréndida } \\
\text { SUBTOTAL } \\
\text { ESTATAL }\end{array}$ & $\begin{array}{c}800 \\
41,400\end{array}$ & $\begin{array}{c}80 \\
20,370\end{array}$ & $\begin{array}{c}720 \\
21,030\end{array}$ \\
\hline \multirow[t]{3}{*}{$\begin{array}{c}\text { San Luis } \\
\text { Potosí }\end{array}$} & Región Altiplano & 4,699 & 2,098 & 2,601 \\
\hline & Zona Media & 3,746 & 2,098 & 1,650 \\
\hline & $\begin{array}{l}\text { Zona Huasteca } \\
\text { SUBTOTAL } \\
\text { ESTATAL } \\
\end{array}$ & $\begin{array}{c}6,536 \\
14,981\end{array}$ & $\begin{array}{l}3,236 \\
7,430\end{array}$ & $\begin{array}{l}3,300 \\
7,551\end{array}$ \\
\hline \multirow[t]{3}{*}{ Sinaloa } & Región Centro & 69,685 & 5,085 & 64,600 \\
\hline & Región Norte & 14,067 & 4,187 & 9,880 \\
\hline & $\begin{array}{l}\text { Región Sur } \\
\text { SUBTOTAL } \\
\text { ESTATAL }\end{array}$ & $\begin{array}{c}33,685 \\
117,437\end{array}$ & $\begin{array}{l}32,165 \\
41,437\end{array}$ & $\begin{array}{c}1,520 \\
76,0000\end{array}$ \\
\hline \multirow[t]{6}{*}{ Sonora } & Región de Cajeme & 7,000 & 7,000 & \\
\hline & $\begin{array}{c}\text { Región de Navojoa } \\
\text { Huatabampo }\end{array}$ & 4,000 & 4,000 & \\
\hline & $\begin{array}{l}\text { Región de Guaymas- } \\
\text { Empalme }\end{array}$ & 4,000 & & 4,000 \\
\hline & $\begin{array}{c}\text { Región de } \\
\text { Hermosillo }\end{array}$ & 38,000 & & 38,000 \\
\hline & Región de Pesquería & 0 & & \\
\hline & $\begin{array}{c}\text { Región de Caborca } \\
\text { SUBTOTAL } \\
\text { ESTATAL }\end{array}$ & $\begin{array}{l}15,000 \\
68,000\end{array}$ & 11,000 & $\begin{array}{l}15,000 \\
57,000\end{array}$ \\
\hline
\end{tabular}

Table 1. Most representatives states of Mexico. (modified from Ramirez-Romero et al., 2006)

Children's Fund) [UNICEF], 2007.) believes that protecting children from exploitation is an integral part of ensuring their right to survival, and to a quality development.

"The fact that they're migrants means that they move from place to place, and so nobody feels completely responsible for fulfilling their basic needs and protecting their rights," says (UNICEF, 2007) Child Protection Officer Theresa Kilbane. The main toxic effects of the pesticides are derived of the inhibition of the enzyme esterase, and they could be implied in the cardiovascular alterations that are observed in the exposed organisms. The determination of the level of erythrocyte cholinesterase or plasmatic, the biological indicator used in the diagnosis of intoxications, like in the monitoring with the ends of prevention, study, or control (Table 2). 


\begin{tabular}{|l|l|l|l|}
\hline Population & $\begin{array}{l}\text { Average } \\
\text { Cholinesterase } \\
\mathrm{U} / \mathrm{mL}\end{array}$ & $\begin{array}{l}\text { Average } \\
\text { Hemoglobin } \\
\mathrm{g} / \mathrm{dL}\end{array}$ & $\begin{array}{l}\text { Average } \\
\text { cholinesterase-adjusted } \\
\text { Hemoglobin U/g }\end{array}$ \\
\hline Men & 4.29 & 13.29 & 32.59 \\
\hline Women & 3.98 & 11.66 & 34.63 \\
\hline Children & 3.87 & 11.99 & 32.65 \\
\hline Average total & 4.22 & 12.89 & 33.1 \\
\hline
\end{tabular}

Table 2. Basal cholinesterase levels and cholinesterase adjusted to hemoglobin in agricultural laborers, Sinaloa, Mexico.

Inside of the parameters to considering the degree of exposure to pesticides is the minimum level of risk for oral exposure to this compounds in humans is of $0.003 \mathrm{mg} / \mathrm{kg} / \mathrm{d}$ and the non-observed adverse effects level of $0.03 \mathrm{mg} / \mathrm{kg} / \mathrm{d}$ (Deacon et al., 1980). However, they have been found in many foods in quantities of between 0.09 and $0.2 \mathrm{mg} / \mathrm{kg} / \mathrm{d}$ (Bullman et al., 2002). On the other hand, the production of organic food is insufficient: To feed 9 billion people in 2050, we urgently need to adopt the most efficient farming techniques available. Today's scientific evidence demonstrates that agro-ecological methods outperform the use of chemical fertilizers in boosting food production where the hungry live -- especially in unfavorable environments. "To date, agro-ecological projects have shown an average crop yield increase of $80 \%$ in 57 developing countries, with an average increase of $116 \%$ for all African projects. Recent projects conducted in 20 African countries demonstrated a doubling of crop yields over a period of 3-10 years" (De Schutter, 2011).

The pesticides of the group of the organophosphate ones produce important functional alterations in various organs and systems of individuals who have contact with these types of substances. The effects reported more frequently are those that are related to changes in the central nervous system. Mice injected with malathion showed an decrement on dendritic morphology in neurons from the hippocampus and in the prefrontal cortex in comparison with the control group (Campaña et al., 2008). However, a percentage of patients present major complications at the level of the cardiovascular system that increase the morbidity and mortality associated with this physiological system. We know that the acute exposure to organophosphate produces bradycardia initially and then tachycardia, the latter effect dosedependent (Aiuto et al., 1993). The mechanisms of generation of the effects of organophosphates have been associated mainly with the irreversible inhibition of acetylcholinesterase in the central and peripheral synapses whose primary function is the degradation of the acetylcholine.

The cardiovascular systems uses cholinergic processes in the sensory mechanisms, integrative and health providers and therefore are likely to be changed due to exposure to organophosphorus compounds (Ballantyne \& Marrs, 1992; Gordon, 1994).

\section{Antecedents}

\subsection{Similarities to other countries}

There are many people who are involved in the migrant farm industry. Migrant farm workers are agricultural workers who move often within a yearly period for employment purposes. The families of migrant farm workers move to follow the planting. Most of these families are second and third generation migrant families. These families are usually very 
poor. The workers and their families are seen in literature as an "invisible" group who are the most disadvantaged and at-risk population in the country. They are not seen, not heard, and not helped.

Children of migrant farm workers are an extremely vulnerable population of children. These children face a transient lifestyle. This lifestyle often begins at birth, and interferes with any hope for a stable education, steady friends, and familiarity with a community. Nearly every migrant child lives in poverty. It has been seen that children as young as 10 are working in the fields. It is estimated that twenty five to forty percent of the farm work is done by young children.

Migrant housing is a critical issue. Migrant workers often cannot afford to build suitable housing. Only thirty percent of the migrant population has comfortable houses. They are forced to live in dirty, overcrowded places or even worse, in tents, cars or even open fields. There are few government laws that require suitable houses, therefore, they get little help in this area. Resources in the area of housing are bare. Some states have begun to build houses and provide loans for low income residents but this does not seem to meet the needs of the migrant farm workers because they are constantly being uprooted and moved because of work situations.

There are numbers of injuries and deaths reported every year due to various accidents, such as, drowning in ditches, poor mechanical equipment, exposure to agricultural chemicals, being out in the sun and other heat related sicknesses. Children are exposed to the exact same conditions as adults, but are more vulnerable to becoming sick.

The life expectancy of migrant farm workers is 49 years compared to the national average of 73 to 75 years. There are many diseases among the migrant people like, malnutrition, maternal malnutrition, dental problems, parasitic infections, hypertension, diabetes, respiratory infections, and sexually transmitted diseases-including HIV/AIDS. There are also many mental health problems too, including, depression, anxiety, and abuse. Many of these health issues are related to not having sanitary living and working conditions. They cannot get help in this area because they cannot afford life insurance. The most commonly identified reasons for children of migrant farm workers dropping out of school include the need to work, the lack of relationships with peers at school, the need to move, getting pregnant, and or getting married. The number of children from migrant farm workers has increased, but the financing of their education has stayed the same. The families of migrant farm workers have to be independent. Families may get separated when the father leaves to find work. This leaves the mother in charge of the children. The mother usually has no money, and no way to provide for the children. Family life for migrant farm workers is extremely stressful because they face survival situations every single day. Children learn early that they are needed and they often help with the family farm work at the cost of their education. The maltreatment of children was significantly higher among migrant farm workers' families. Migrant farm workers are found to abuse their children in some states. It is more serious in some states than in others.

Migrant farm workers experience life and death situations every single day. The farm workers themselves do everything they can to support and keep a decent family. They are in great danger. But, their children are in even more danger of becoming hurt, they are innocent people that deserve a chance at the best life that they can get. They have tried to be seen, noticed and understood in the past. They have reached out for help but were rejected. 
Their cries for help are unheard by the rest of the people of the world. They need to be helped. They need to be able to have a chance, a dream, a life.

The pesticide intoxication is an important cause of morbidity and mortality in the countries in development, although it has been reported that the fourth part of the pesticides that are wasted away in the entire world, is consumed by these countries. However, every year 3 million severe cases of intoxication and 22000 deaths are recognized; (99\% in the 3rd world) the collateral effects resultants of the indiscriminate use of the pesticides are disseminated in humans where these compounds alter the biochemical and physiologic functions (Banerjee, 1996, 1999; Selgrade, 1999).

The toxicity for pesticides happens mainly in underdeveloped countries, such as Mexico, and concretely in the State of Sinaloa, which is one of the States of higher agricultural activity and shown to produce the best organic corn (non transgenic) worldwide recognizable, subsequently where they are used perhaps but agro-chemicals in the country forces us to evaluate the factors of risk for the health of the residents in function of the multi-exposure.

The dangerous effects that exist for small quantities repeated over a period of time, usually years, determine the chronic effects of the compounds (Hock, 1999; Henderson et al., 2002). The chronic toxicity of a pesticide is more difficult to determine through laboratory analysis than the acute toxicity (Marrs, 2000; Varagic et al., 2001).

The effects on skin or organs and/or sensitive systems by toxins, such as: the cardiovascular system, the blood, the gastrointestinal tract and liver. The Environmental Diseases System defines cardiovascular or sanguine toxicity as the adverse effects in the cardiovascular systems and hematopoietic that are caused by the exposure to chemical substances. Specific illnesses caused by a cardiovascular or sanguine toxic include arterial hypertension, hardening of the arteries, heart arrhythmias, and factors of the coagulation and decrease of the sanguine flow toward the heart.

There are reports of data in the literature (Jeffrey, 1994; Zeimer, 1984; and Holmes., 1956) which relate to patients poisoned with organophosphate insecticides having had disorders of platelet function and blood coagulation and have suggested the importance of routine coagulation tests in these patients.

The (Environmental Protection Agency [EPA], 2007), affirms that children are more susceptible to organic damage: the reasons: first, the internal organs are still in a developmental process, for which these substances types can block the necessary blood components and vital nutrients for the cellular growth. In second place, children consume more food, in proportion with their corporal weight than the adults. This also reinforces the effect of the pesticides because exposure is more probable exposure per orally. Finally, the (EPA, 2007), claims that there are environments common to the children that increase their exposure to the compounds in domestic use; playing on the floor or in the grass, with pets, sucking polluted objects etc.

The question is: why are the pesticides in the foods of children? They have not taken the appropriate precautions because the children don't demand it. They are perhaps the minority group least valued at the moment in the entire world, constituting a sub-class; according to asseverations when we refer to the stratification, we locate children at the bottom in terms of power. This is especially true of the smallest children in whom the cells are in development more than in adults. In terms of power the children are one of the smaller power groups in our society in general. Therefore, the contamination by pesticides is not a priority, since the cost of fixing the problem is bigger than the cost of the health of the children, from the point of view of the industry. 
The (Protection Action Network North America [PANNA], 2009), through the (Pesticide Action Network Update Service) [PANUPS] and their spokeswoman the Dr. Susan Kegley affirmed in the Los Angeles Times that the farmers are not making progress toward the use of less toxic alternative pesticides, which is a problem that should be pointed out.

\subsection{Oxidative stress}

The blood pathologies seem to be a sensitive indicator in the exposure to the pesticides as well as the oxidative stress. In a study, data suggested that oxidative stress may be involved in the effects of chlorpyrifos (an organophosphate pesticide). Significantly increased levels of malondialdehyde were found in aorta and plasma samples in rats; the nitric oxide takes place in several types of cells and it is studied well in the vascular endothelium. While this specie is not too much reactive it reactivates (scarce function oxidizer), even low physiologic concentrations (to $<100 \mathrm{nM}$ ), it reacts quickly with oxygen to produce nitrogen dioxide $\left(\mathrm{NO}_{2}-\right)$ that in turn can react with the nitric oxide to produce nitrogen trioxide $\left(\mathrm{N}_{2} \mathrm{O}_{3}\right)$; the nitrites showed elevation in plasma, not only but also the superoxide dismutase enzyme activity in the aorta sample was statistically significant, as in plasma where its activity was elevated (Alvarez et al., 2008).

The biochemical reactions oxidize-reduction or REDOX, result in the formation of species reactive oxygen, such as hydrogen peroxide, radical and hydroxyl superoxide, constantly attacking the organism and occurring as a normal part of cellular metabolism (Pérez \& Pérez, 2000). The increased concentrations of reactive species of oxygen contribute to the aggravation of the cell function, and has been reported to coincide with pathologies like damaging accelerated vascular (microcirculation) that accompanies the hypertensive syndrome (have been kept to speculation and without pilot bases firmly). Indirect evidence has suggested that the key word may be related to reinforcement in the production of oxygen radical (Suzuki et al., 1995). For example, nitric oxide and radical superoxide play important roles as molecules vascular signaling but, to cause peroxynitrite triggered an imbalance between these free radicals with important implications for the vascular patophysiology (Guzik et al., 2002). In the different organs several defense mechanisms exist to minimize the effect of the oxidative stress. Among them are substances of under molecular weight such as alpha-tocopherol, glutathione and ascorbic acid and mainly enzymes like superoxide dismutase (Clapés et al., 2001).

The reduction of the oxidative excessive damage is one of the mechanisms to minimize the cellular devastation (Uchiyama \& Mihara, 1978). The prevention of intoxications requires the recognition of the factors that favor it, the attention to the focus of lipoperoxidation and oxidative stress, parameters that should clarify the changes in the enzymatic activities in the redox system that can happen after the exposure to xenobiotics and its relationship with alterations of arterial pressure (Kehrer, 1993).

\subsection{Basic concepts of blood coagulation}

In humans and other vertebrates, the blood coagulation system is a first line of defense against vascular trauma. In case of a wound (whether unintentional in accidents or intentional in surgery), blood coagulation rapidly forms a blood clot; the approximate time that it takes for skin bleeding to stop is on average $2-5$ minutes if the system is functioning correctly. If there is a defect at some point of the coagulation system, bleeding may be 
markedly prolonged. The vertebrate blood coagulation system consists of cellular elements (blood platelets, white cells, to some extent red cells and micro vascular remnants or micro particles) and proteins (coagulation enzymes and co-factors, and a number of anticoagulant proteins). When blood coagulation is triggered, cells and membrane remnants interact with coagulation factors assembling effective macromolecular complexes that contribute to the formation of fibrin molecules. These fibrin molecules and cells constitute the blood clot formed at the point of damage to the blood vessel. Bled of the small vessels it can be stopped by vasoconstriction and the formation of platelets, but the formation of a clot usually happens as part of the normal process of hemostasis, the factors of the clotting are component critical in the formation of a thrombus. Blood clotting is a sequential process of biochemical reactions involving plasma proteins, phospholipids, and ions of Ca. Most of the coagulation factors involved in the clotting process are designated with Roman numerals. The activated form of an enzyme factor appears with Roman numeral followed by the suffix - a, while the inactive factors are indicated by the Roman numeral alone. For example, prothrombin is designated as factor II, in any way, in this active state is: IIa, thrombin. Nonenzymatic factors do not have these designations. It is important to note that the Roman numerical designations do not indicate the sequence of reactions in the agglutination process, for example, the $\mathrm{X}$ factor precedes the factor II in the clotting process.

The proteins are clotting factors that have four characteristics:

1. A deficiency of factor that usually produces a tendency to bleed with the exception of factor XII, prekallikrein (Fletcher factor) and high molecular weight kininogen.

2. The chemical and physical characteristics are known factors.

3. Factor synthesis is independent of other proteins.

4. The factor can be determined in the laboratory (Table 3)

In the sense of developing an understanding of coagulation theory and the principles underlying laboratory procedures, it is useful to compare the characteristics of various clotting factors. There are three sets of factors: the group fibrinogen, prothrombin group and the control one.

Reports of data exist in the literature (Jeffrey C. Murray, 1994; M. Zeimen, 1984; and Holmes J., 1956), where they report that patients intoxicated with pesticides organophosphate presented disorder in the platelet function and the sanguine clotting for which the importance of making tests of routine clotting in this type of patients is suggested.

\subsection{Altered ions in the system of clotting and hemostasis}

The pesticides affect the sanguine clotting in a two-phase way. This way, it has been that the reduction of clotting is a phenomenon that is presented in the workers that manipulate or they are exposed to these compounds, due to the appearance of times of lingering prothrombin and to deficiency of the factors V and VII (Holmes, 1956). (Zeimen, 1984), studied the function of the platelets and the parameters of the sanguine clotting in nine patients intoxicated with pesticides organophosphates. In five of the nine patients there was a marked tendency to the appearance of hemorrhages. Also, the thrombolytic was irregular in all of the patients and the abnormalities of the clotting were more marked in the cases of severe intoxication. On the other hand, the continuation of the time of prothrombin has been reported, due to the transitory decrease of the activity of the factor VII, in a baby of 1, Blood samples by venous puncture were obtained; in addition, a questionnaire for labor and 


\begin{tabular}{|c|c|c|c|}
\hline Characteristic & \multicolumn{3}{|c|}{ GROUPS } \\
\hline Factor & Ia & $\mathrm{II} \mathrm{b}^{\mathrm{b}}$ & IIIc \\
\hline Molecular weight & High & Low & $i$ \\
\hline Plasma & Present & Present & Present \\
\hline Serum & Absent & Present, except II & Present \\
\hline Absortion $\left(\mathrm{BaSO}_{4}\right)$ & Not & Yes & $\begin{array}{l}\text { nothing or } \\
\text { partially }\end{array}$ \\
\hline Destruction & Thrombin, plasmin & & \\
\hline Stability & $\begin{array}{l}\text { Factors V and VIII } \\
\text { unstables }\end{array}$ & Stable to the heat & Stable \\
\hline Increase & $\begin{array}{l}\text { inflamation, } \\
\text { pregnancy, stress and } \\
\text { fear, oral } \\
\text { contraceptives }\end{array}$ & $\begin{array}{l}\text { Pregnancy } \\
\text { contraceptives orales }\end{array}$ & \\
\hline Decrement & & Oral anticoagulant & \\
\hline
\end{tabular}

aGroup I: Fibrinogen group (Factors I, V,VIII,XIII).

bGroup II: Protrombin group (Factors II, VII, IX,X).

cGroup III: Contact group (Factors XI,XII, Fletcher, factors Fitzgerald).

Table 3. Characteristics of clotting

clinical history was applied. The results indicate that the organophosphates ones prolong the time of prothrombin and diminish the percentage of retraction of the clot after the exposure to these pesticides in the migrant workers of the field. The effect with a $\mathrm{P} \leq 0.01$ appeared, compared with its controls. Of the individually studied factors of the coagulation, factor II was of the most sensitive to these compounds, statistically very significant changes occurring (Ps 0.01). Men and women of 8 to 50 years old and in voluntary form were studied randomly. Blood samples by venous puncture were obtained; (Table 4) in addition, a questionnaire for labor and clinical history was applied.

\begin{tabular}{|l|l|}
\hline \multicolumn{1}{|c|}{ PARAMETER } & \multicolumn{1}{c|}{ METHOD } \\
\hline - Time of bleeding & - Ivy \\
\hline -Retraction of the clot & - Platt \\
\hline -Time of coagulation & - Lie-White \\
\hline - Count of platelets & - Brecher \\
\hline - Time of partial thromboplastin & - Langdell \\
\hline - Time of prothrombin & - Quick \\
\hline - Individual Activity of factors of coagulation & - Kits de Sigma Chemical \\
\hline - Activity of seric pseudocholinesterase & - Merck \\
\hline - Activity of Erythrocyte Acetilcholinesterase & - Magnotti \\
\hline
\end{tabular}

Table 4. Procedures to obtain the samples 


\begin{tabular}{|c|c|c|c|c|c|c|c|}
\hline PRAMETERS & $\mathrm{TP}$ & $\mathrm{TPT}$ & Plat & Hto & $\mathrm{Hb}$ & Red cel. & $\begin{array}{l}\text { White } \\
\text { cel. }\end{array}$ \\
\hline \multicolumn{8}{|l|}{ Mean } \\
\hline Control & 12.51 & 31.80 & 215,800 & 41.95 & 14.72 & $4,959,000$ & 6,556 \\
\hline Exposure & 12.85 & 31.75 & 224,500 & 39.45 & 13.23 & $4,620,000$ & 7,844 \\
\hline \multicolumn{8}{|l|}{ Std Deviation } \\
\hline Control & 0.5203 & 1.713 & 40,820 & 3.644 & 1.318 & 92,756 & 1,771 \\
\hline exposure & 0.5796 & 2.121 & 49,970 & 3.967 & 1.384 & 40,522 & 1,775 \\
\hline \multicolumn{8}{|l|}{ Std Error } \\
\hline Control & 0.08227 & 0.2708 & 6,455 & 0.5762 & 0.2085 & 14,666 & 280.1 \\
\hline Exposure & 0.09164 & 0.3354 & 7,900 & 0.6273 & 0.2188 & 6,407 & 0.2807 \\
\hline \multicolumn{8}{|l|}{$\begin{array}{l}\mathbf{P} \text { Value } \\
\mathrm{P}<0.0001\end{array}$} \\
\hline
\end{tabular}

Table 5. Parameters measured in migrant laborers (Sin. Mex).

Using an Analysis of variance (ANOVA), plus Dunnet's multiple comparison test, we obtained the following results: in the first case: (Figure 2.), the column $C$ (control group) shows 14.71 of the mean of this parameter, with a standard deviation of 1.318 and standard error of 0.208 vs the column D, with a mean of 13.23 , std deviation of 1.384 , std error of 0.218 resulting in a significant change in the hemoglobin parameter.

In the second case (Figure 3.), our findings show contrasts as follows: the column A, control group shows 12.33 of platelets vs 14.57 of the column B seconds. The column C, control group for thromboplastin partial time 31.375 vs column D, 34.27 seconds (Table 5).

\section{Hematological Parameters (migrants [Sin-Mex] 2011)}

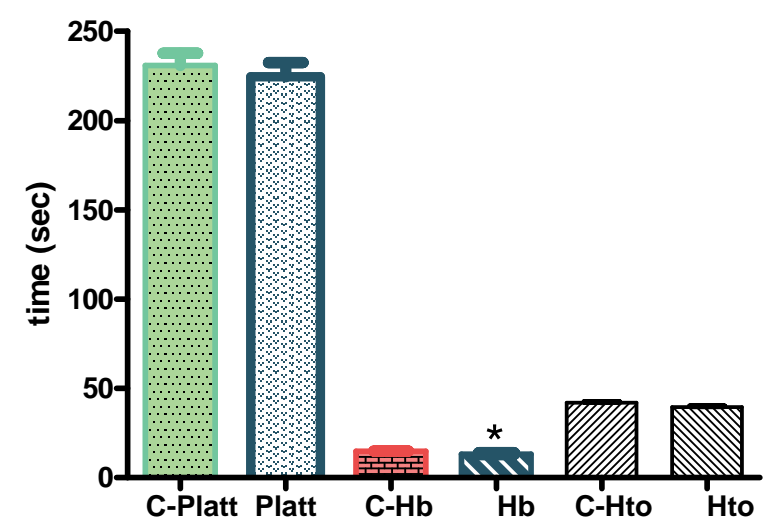

C-Platt (control platelets group) C-Hb (control hemoglobin group) C-Hto (control hematocrit group)

Fig. 2. The graphic does not show statistically significant changes in the values of platelets and hematocrit, but it shows significant change $(\mathrm{P}<0.01)$ in hemoglobin value of the exposed group. 
Coagulation Parameters (migrants [Sin-Mex] 2011)

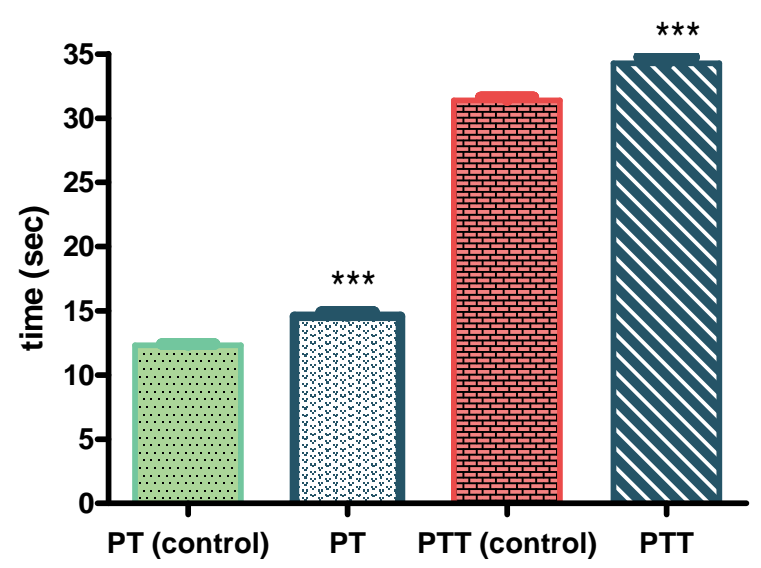

Fig. 3. Coagulation parameters obtained. The graphic shows altered coagulation times compared with the control group; being highly significant statistically $(\mathrm{P}<0.0001)$.

\section{Conclusion}

Navolato, Sinaloa, Mexico. This study focused on the function of platelets and the parameters of the sanguineous coagulation in migrant agricultural laborers exposed to pesticides. The aim of this study was to analyze the early effects on the sanguineous coagulation of the organophosphates ones.

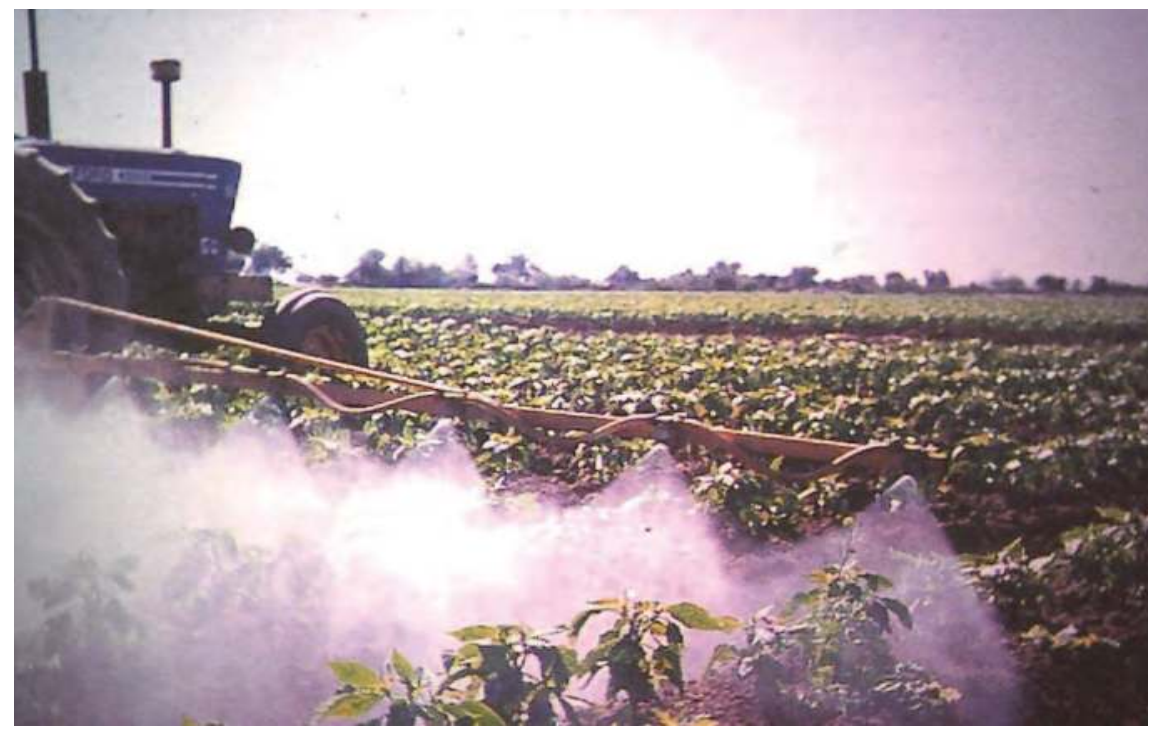

Fig. 4. Pesticide fumigation in the fields of Sinaloa, Mex., (2011). 


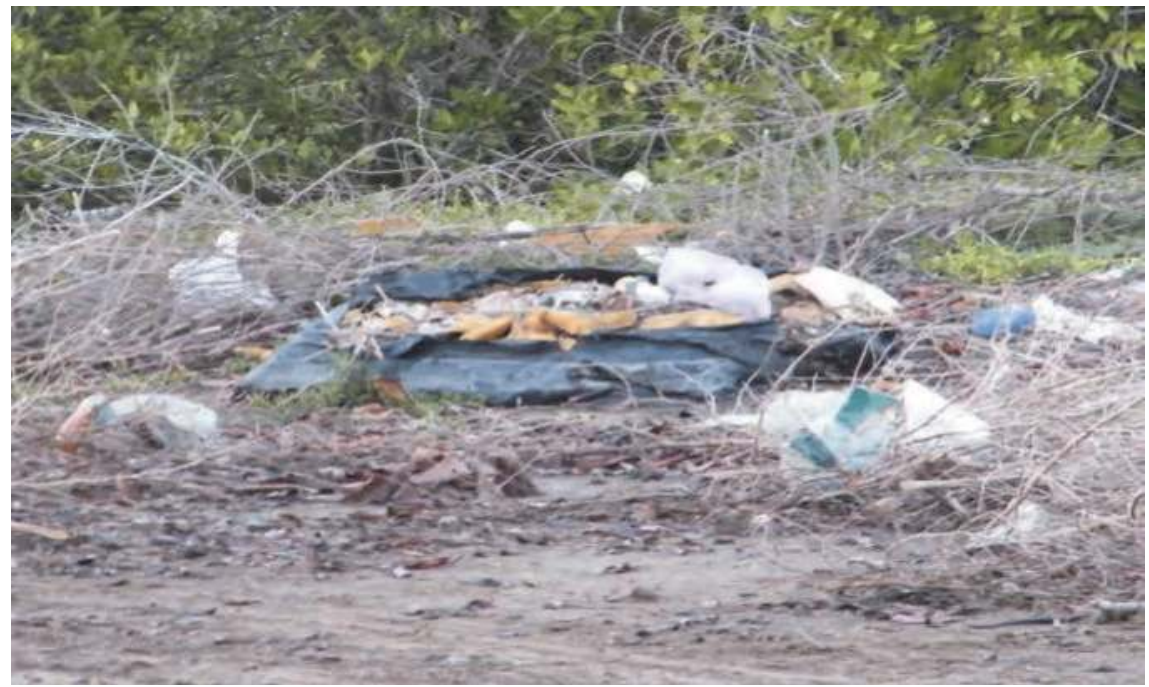

Fig. 5. Diverse agro chemical waste around habitat zone. Sinaloa, Mex., (2011)

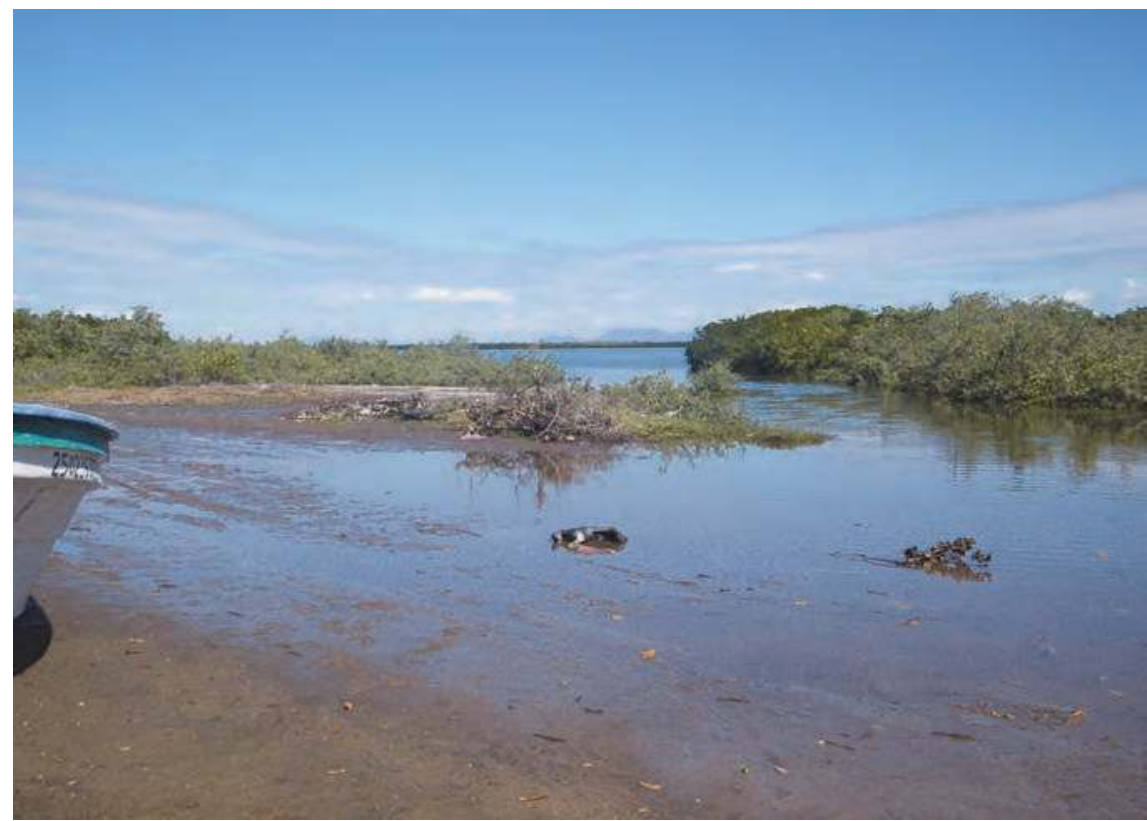

Fig. 6. Some wild animals probably become intoxicated due to the agro chemical waste. Sinaloa, Mex., (2011)

Prothrombin (factor II) is the most sensitive parameter affected by these compounds so that we can deduce that there is a correlation with the results of the study related to individual clotting factors and the factor II presents a decrease in activity of more than $50 \%$ indicating a 
selective damage by these pesticides studied on the system of coagulation and hemostasis. These findings are consistent with reports by Sweeney \& Lyon, 1999, who found a selective effect of malathion on blood coagulation activity against the locomotor system. Some altered coagulation parameters could be used as early markers of exposure to organophosphate type.

Some altered coagulation parameters could be used as early markers of exposure to organophosphate pesticides. Although there are some examples of successful cooperation between government, farm owners and local communities to provide a safe environment for migrant children, more needs to be done. But many companies do not want to cooperate with these institutions to improve the living conditions of the migrant workers. There is still a long way to go.

\section{Acknoledgments}

CONACyT No.174311-126555 and DGIP-UAS No. 273-274., Bartolo López Quintero, Blanca I. Cabanillas Espinoza, Rosario Beltrán Ruiz, Elva G. Verdugo Aguilar, from Laboratory of Hosp. C. Cul., Sin. We also acknowledge Elaine Bell for her review of the manuscript.

\section{References}

Aiuto, LA, Pavlakis SG, \& Boxer RA. (1993). Life-threatening organophosphate-induced delayed polyneuropathy in a child after accidental chlorpyrifos ingestion. J Pediatr 122(4):658-660

Alvarez, A.A. (2008). Chlorpyrifos induces oxidative stress in rats. Toxicological and Environmental Chemistry. Faculty of Medicine, University of Sinaloa, Mexico; 90: $5,1019-1025$

Ballantyne \& Marrs, (1992). Overview of the biological and clinical aspects of organophosphates and carbamates. In: Ballantyne \& Marrs TC (Eds.) Clinical and Experimental Toxicology of organophosphates and carbamates, ButterworthHeinemann, Oxford, pp.3-14

Banerjee, BD. (1999). The influence of various factors on immune toxicity assessment of pesticide chemicals. Toxicol Lett; 107: 21-31.

Bullman, S.; Belal E.A. \& Wasiuddin A. K. (2002). Locomotor and locomotor and sensory motor performance deficit in rats following exposure to pyridostigmine bromide, DEET, and permethrin, alone and in combination. University Medical Center; and VA Medical Center, Durham, North Carolina 34: 27- 71

Campaña, A.D. (2008). Dendritic Morphology on Neurons From Prefrontal Cortex, Hippocampus, and Nucleus Acumbens Is Altered in Adult Male Mice Exposed to Repeated Low Dose of Malathion. Wiley InterScience. SYNAPSE 62: 283-290

Cortés-Genchi P.; Villegas-Arrizón, A.; Aguilar-Madrid, G.; Paz Román,MP.; MarurisReducindo, M.; Juárez-Pérez, CA.(2008) Sintomas ocasionados por plaguicidas en trabajadores agrícolas Rev Med Inst Mex Seguro Soc ; 46(2): 145-152

Clapés, S.; Torres, O.; Companioni, M.; Villariño, U.; Broche, F. \& Céspedes E M. (2001). Peroxidación lipídica y otros indicadores de estrés oxidativo en pacientes diabéticos. Rev. Cubana Invest Biomed; 20(2):93-98

De Schutter, O. (2011). UN Special Reporter on the right to food and author of the report "Agroecology and the right to food," published March 8, No. 267 
Deacon, MM.; Murray, JS. \& Pilny MK. (1980). Embryotoxicity and fetotoxicity of orally administered Chlorpyrifos in mice. Toxicol Appl Pharmacol 54(1):31-40

Gordon, CJ. (1994).Thermoregulatory effects of chlorpyrifos in the rat; long- Term changes in cholinergic and noradrenergic sensitivity.Neurotoxicol Teratol 16 (1):1-9

Grammont, H., Lara F.S.M., Sánchez MJ. (2004). Los grupos domésticos en el nuevo contexto de la migración rural., UNAM-IIS 357-386

Guzik, TJ, J. NE, West, RP,Taggart, DP, \& Channon KM. (2002). Nitric Oxide Modulates Superoxide Release and Peroxynitrite Formation in Human Blood Vessels Hypertension;39;1088-1094.

Hock, WK. \& Brown, CL. (1999). Toxicity and Potential Health Effects of Pesticides. Agrichemical Fact Sheet. 14 (7): 46-52

Henderson, RF.; Barr, EB.; Blackwell, WB.; Clark, CR.; Conn, CA.; Kalra, R.; March, TH.; Sopori, ML.; Tesfaigzi, Y.; Ménache, MG. \& Mash DC. (2002). Response of Rats to Low Levels of Sarin. University of N.Mexico, Elsevier Science (USA) Toxicol Appl Pharmacol. 184:67-76

Kehrer, JP. (1993). Free radicals as mediators of tissue injury and disease. Crit Rev Toxicol; 23: 21-48.

Marrs, TC. (2000). The Health Significance Of Pesticide Variability In Individual commodity items Food Additives and Contaminants, 17 (7): 487-489

Martinez-Murillo, J. (2006) Mecanismos de activación de la Coagulación. Rev Med Inst Mex Seguro Soc; 44 (Supl 2): 51-58

Palacios-Nava, ME.; Moreno-Tetlacuilo LMA. (2004). Health differences between male and female migrant agricultural workers in Sinaloa, Mexico.Salud Publica Mex;46:286293.

Pérez, GPL. \& Pérez de AJL. (2000). Métodos para medir el daño oxidativo. Rev Cubana Med Milit 29(3): 192-8

Romero, SJ.; Palacios, ND. Velazco, S D. (2006). Diagnóstico sobre la condición social de las niñas y niños migrantes internos, hijos de jornaleros agrícolas en 17 Estados del País. Programa de Atención a Jornaleros Agrícolas. Secretaría de Desarrollo Social. (SEDESOL).Unicef. pág. 31.

Selgrade, MJ K. (1999). Linking environmental agents and autoinmune disesase: an agenda for future research. Enviromental Health Perspectives 107.

Suzuki, H.; Swei, A.; Zweifach, BW. \& Schmid-Schönbein, W. (1995). In vivo Evidence for Microvascular Oxidative Stress in Spontaneously Hipertensive Rats. Hipertension. 25:1083-1089

Uchiyama M, Mihara M. (1978). Determination of Malondialdehyde precursor in tissues by thiobarbituric acid test. Analytical Biochemistr; 86: 271-278

Varagic, VM, Prostran MS, Stepanovic S, Savic J. Vujnov S. (2001). Organophosphates and toxicity. Department of Pharmacology, Faculty of Medicine, Belgrade, 43 (32): 65-71

Consulted web sites for the secondary heading : 2.1 Similarities to other countries http://ericfacility.nrt/database/ERIC_Digests/ed471487.html on October 1, 2003 http://www.naspcenter.org/teachers/migrantchildren.html on October 1, 2003 http://www.rtfcam.org/report/volume_23/NO_2/article-1.htm http://www.savannahnow.com/stories/051798/LOConionbleakout.html on October 1, 2003 


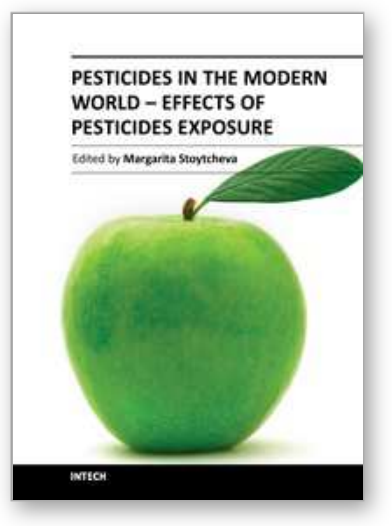

\author{
Pesticides in the Modern World - Effects of Pesticides Exposure \\ Edited by Dr. Margarita Stoytcheva
}

ISBN 978-953-307-454-2

Hard cover, 376 pages

Publisher InTech

Published online 12, September, 2011

Published in print edition September, 2011

The introduction of the synthetic organochlorine, organophosphate, carbamate and pyrethroid pesticides by 1950â $€^{\mathrm{TM}} \mathrm{s}$ marked the beginning of the modern pesticides era and a new stage in the agriculture development. Evolved from the chemicals designed originally as warfare agents, the synthetic pesticides demonstrated a high effectiveness in preventing, destroying or controlling any pest. Therefore, their application in the agriculture practices made it possible enhancing crops and livestockâ $€^{\mathrm{TM}^{\mathrm{M}}} \mathrm{s}$ yields and obtaining higher-quality products, to satisfy the food demand of the continuously rising worldâ $€^{\mathrm{TM}_{\mathrm{M}}}$ population. Nevertheless, the increase of the pesticide use estimated to 2.5 million tons annually worldwide since 1950 ., created a number of public and environment concerns. This book, organized in two sections, addresses the various aspects of the pesticides exposure and the related health effects. It offers a large amount of practical information to the professionals interested in pesticides issues.

\title{
How to reference
}

In order to correctly reference this scholarly work, feel free to copy and paste the following:

Anthon Alvarez A. and Alba D. Campaña S. (2011). Migrant Farm Workers Exposed to Pesticides in Sinaloa, Mexico, Pesticides in the Modern World - Effects of Pesticides Exposure, Dr. Margarita Stoytcheva (Ed.), ISBN: 978-953-307-454-2, InTech, Available from: http://www.intechopen.com/books/pesticides-in-the-modernworld-effects-of-pesticides-exposure/migrant-farm-workers-exposed-to-pesticides-in-sinaloa-mexico

\section{INTECH}

open science | open minds

\section{InTech Europe}

University Campus STeP Ri

Slavka Krautzeka 83/A

51000 Rijeka, Croatia

Phone: +385 (51) 770447

Fax: +385 (51) 686166

www.intechopen.com

\section{InTech China}

Unit 405, Office Block, Hotel Equatorial Shanghai

No.65, Yan An Road (West), Shanghai, 200040, China 中国上海市延安西路65号上海国际贵都大饭店办公楼 405 单元

Phone: +86-21-62489820

Fax: $+86-21-62489821$ 
(C) 2011 The Author(s). Licensee IntechOpen. This chapter is distributed under the terms of the Creative Commons Attribution-NonCommercialShareAlike-3.0 License, which permits use, distribution and reproduction for non-commercial purposes, provided the original is properly cited and derivative works building on this content are distributed under the same license. 